\title{
Do local environmental factors structure the trophic niche of the splash tetra, Copella arnoldi? A test in an Amazonian stream system
}

\author{
Bruno Eleres SOARES ${ }^{*} \mathbb{\oplus}$, Naraiana Loureiro BENONEE ${ }^{2,3}$, Daniela Cristina Oliveira ROSA ${ }^{1}$, \\ Luciano Fogaça de Assis MONTAG² \\ Universidade Federal do Rio de Janeiro, Instituto de Ciências Biológicas, Laboratório de Ecologia de Peixes, Av. Carlos Chagas Filho, 373, Ilha do Fundão, 21941-902، \\ Rio de Janeiro, RJ, Brazil \\ 2 Universidade Federal do Pará, Instituto de Ciências Biológicas, Laboratório de Ecologia e Conservação, Av. Augusto Corrêa, 01, Guamá, 66075-110, Belém, PA, Brazil \\ ${ }^{3}$ Museu Paraense Emílio Goeldi - MPEG, Programa de Capacitação Institucional, Av. Magalhães Barata, 376, 66050-170, São Brás, Belém, PA, Brazil \\ * Corresponding author: soares.e.bruno@gmail.com; (D) https://orcid.org/0000-0001-5678-0403
}

\section{ABSTRACT}

Environmental variation affects the availability of spatial and trophic resources in Amazonian streams and may be important factors structuring the diet of fishes. We analyzed the diet composition and trophic niche breadth of the lebiasinid splash tetra, Copella arnoldi, aiming to evaluate how environmental variation in Amazonian streams affects the species trophic niche. Fish were captured and environmental factors were recorded in 20 streams in the Caxiuanã National Forest, in the eastern Amazon, in November 2010. We made a semi-quantitative analysis of stomach contents of 200 individuals. Copella arnoldi exhibited an omnivorous diet composed mainly by detritus and allochthonous invertebrates. Environmental variation (stream width, stream depth, canopy cover and flow) did not affect the diet composition or trophic niche breadth of the species, possibly due to the regional integrity of the forest within the boundaries of the protected area. Riparian cover probably minimizes the effect of the small-scale variations in food resources, thus leading to a locally homogeneous diet composition in the splash tetra $C$. arnoldi.

KEYWORDS: environmental variation, Lebiasinidae, niche breadth, trophic ecology, Brazilian Amazon

\section{Fatores ambientais influenciam o nicho trófico do tetra Copella arnoldi? Um teste em um sistema lótico amazônico}

\section{RESUMO}

Variaçóes ambientais afetam a disponibilidade de recursos espaciais e tróficos em igarapés amazônicos e podem ser fatores importantes estruturando a dieta de peixes. Analisamos a composição da dieta e a amplitude de nicho trófico do lebiasinídeo Copella arnoldi, tendo como objetivo avaliar como a variação ambiental em igarapés amazônicos afeta o nicho trófico da espécie. Indivíduos foram capturados e fatores ambientais foram medidos em 20 igarapés da Floresta Nacional de Caxiuanã, na Amazônia Oriental, em Novembro de 2010. Fizemos uma análise semi-quantitativa do conteúdo estomacal de 200 indivíduos. Copella arnoldi apresentou uma dieta onívora composta predominantemente por detritos e invertebrados alóctones. A variaçáo ambiental (largura e profundidade do igarapé, cobertura de dossel e correnteza) não afetaram a composição da dieta ou a amplitude de nicho trófico da espécie, possivelmente devido à integridade regional da floresta na área protegida. A cobertura ripária provavelmente minimiza os efeitos da variação ambiental nos recursos tróficos, levando, assim, a uma dieta localmente homogênea de C. arnoldi.

PALAVRAS-CHAVE: amplitude de nicho, ecologia trófica, Lebiasinidae, variação ambiental, Amazônia brasileira

\section{INTRODUCTION}

The use of trophic resources by fish is greatly affected by temporal and spatial variation in food resources (Abelha et al. 2001; Silva et al. 2014; Peterson et al. 2017). Major examples are seasonal reproductive flights of winged ants and mayflies, or the fruitification of plants in marginal vegetation, which module the consumption of prey by numerous fish species (Netto-Ferreira et al. 2007; Correa and Winemiller 2014; Barbosa et al. 2015). Spatial variation in limnological factors and the physical structure of the stream and surrounding vegetation may affect the fitness of the consumer or the availability of prey (Pusey and Arthington 2003), thus affecting the diet of fishes. 
Spatially structured environments are quite common in freshwater systems. Environmental variations from smaller $\left(1^{\text {st }}\right.$ to $3^{\text {rd }}$ order) to larger $\left(4^{\text {th }}\right.$ to $5^{\text {th }}$ order $)$ streams decrease the relative importance of allochthonous input to aquatic systems, according to the River Continuum Concept (Vannote et al. 1980). In small streams, this input is important to local communities, as it affects not only the diet of a singular species, but also the size of the food web and the number of trophic guilds (Vannote et al. 1980; Nakano et al. 1999; Recalde et al. 2016). There is also evidence that spatially related variation in environmental conditions and the physical structure of streams affect food resources and the diet of fishes at smaller scales (Ceneviva-Bastos et al. 2010; Zeni and Casatti 2014).

In order to evaluate how small-scale variations in the physical structure of streams (stream width, stream depth and canopy cover) and in limnological conditions (flow) affect the diet of fish species, we studied the diet of the splash tetra Copella arnoldi (Regan 1912) in streams of the National Forest of Caxiuaná, in the eastern Amazon. Copella arnoldi (Characiformes: Lebiasinidae) has a high commercial importance as ornamental fish and is the most abundant species in the streams of Caxiuanã (Montag et al. 2008; Benone 2012; Freitas et al. 2018). Lebiasinids are omnivorous and opportunistic species, and most studies found that they feed mainly on allochthonous arthropods (Román-Valencia 2004; Kemenes and Forsberg 2014), although Silva et al. (2016) reported allochthonous plant material (e.g. leaves, fruits and stems) as their main food source.

Aiming to evaluate the spatial variation in the diet of C. arnoldi in the streams of Caxiuaná, we analyzed: (i) the diet composition and general feeding strategies; and (ii) how environmental factors explained the variation in the diet composition and populational niche breadth of the species. We provide information about how small-scale natural variations may affect the diet of fishes, which may be useful in the current scenario of fast changes in the structure of the aquatic environments in Amazonia.

\section{MATERIAL AND METHODS}

\section{Sampling sites}

Twenty streams ( $1^{\text {st }}$ to $3^{\text {rd }}$ order) were sampled in the Caxiuanã National Forest, a protected area located in the region of the Lower Anapu River, Pará State, Brazil (Figure 1). Distances among sampled streams vary, but are large in average (mean = $35.23 \mathrm{~km}$; range $=1.3-71.08 \mathrm{~km}$ ). The Caxiuanã National Forest is covered predominantly by dense lowland terra-firme rainforest ( $85 \%$ of its total area) (Lisboa 2002). Local climate is tropical hot and humid, corresponding to Köppen's Am type, with a well-defined seasonality and a short dry period (Peel et al. 2007). The mean air temperature is $26.7^{\circ} \mathrm{C}$, ranging from a minimum of $23^{\circ} \mathrm{C}$ to a maximum of $32.7^{\circ} \mathrm{C}$. Mean annual precipitation is around $2000 \mathrm{~mm}$, reaching a mean
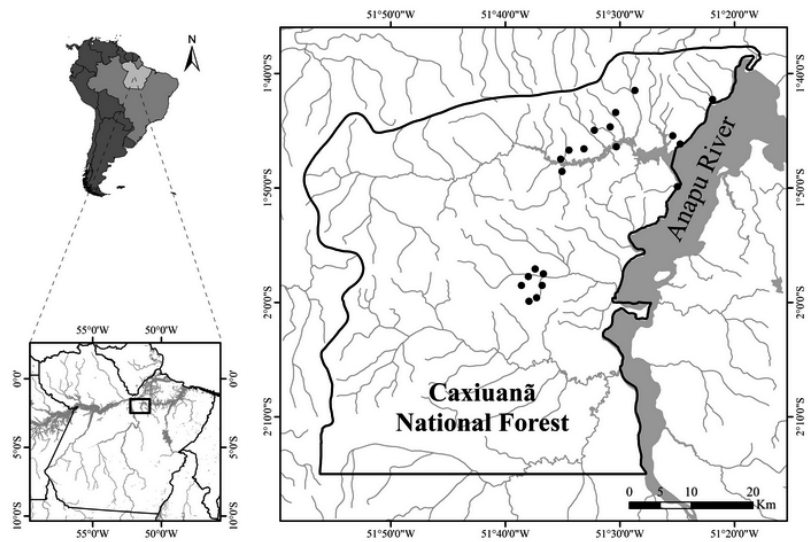

Figure 1. Location of the Caxiuanã National Forest within the lower Anapu River basin, Brazil. Circles represent the 20 stream sites where the specimens of Copella arnoldi were sampled.

monthly maximum of $379 \mathrm{~mm}$ in March and a minimum of $50 \mathrm{~mm}$ in October (Lisboa 2002). The lower Anapu River reaches its highest mean water level in April and May (180 $\mathrm{cm}$ ), dropping to a minimum of $120 \mathrm{~cm}$ in November and December (Lisboa 2002).

Caxiuanã streams have acidic water $(\mathrm{pH} \approx 5.5)$, streambeds densely covered by leaf litter and trunks, shallow depth $(<30 \mathrm{~cm})$ and a main channel associated with permanent floodplains (Montag et al. 2009). The Caxiuanã hydrographic system is characterized as a ria lake, derived from the drowning of the valleys of the Anapu River during the Holocene (Behling and da Costa, 2000). In this type of system, the river system resembles a lake, with enlarged cross-sections near the mouth, very reduced flows, and an accumulation of fine sediments (Irion et al. 2009; Montag et al. 2009).

\section{Environmental variables}

Environmental variables were measured prior to the collection of fish specimens. At each stream site, we measured the abiotic variables three times, one at each of three equidistant points ( $25 \mathrm{~m}$ between each pair) along the stream, and then averaged the three measures to represent the stream site. The following environmental variables were measured: (i) stream depth (m); (ii) stream width (m); (iii) flow velocity $\left(\mathrm{m} \mathrm{s}^{-1}\right)$; and (iv) canopy opening (\%). These variables are considered some of the most relevant for the study of fish assemblages in terra-firme streams (Allan and Castillo 2007). We did not measure substrate type, frequently considered as one of the most important variables affecting fish assemblages, because of the very low variability in drowned streams (Montag et al. 2009). We found a large amount of leaf litter and wood debris accumulated on the bottom of most streams, which reached up to $1 \mathrm{~m}$ in depth.

Stream depth and width were measured using a surveyor's tape. Flow velocity was estimated by recording the time it took 
a floating object to cover a predetermined distance. Canopy opening was analyzed using digital photographs taken with a camera located $1 \mathrm{~m}$ above the water surface. We used the same camera with the same parameters at all sampling points. Photographs were converted into black and white to calculate the percentage of white pixels, considered as canopy opening, in the image (Teresa et al. 2016).

\section{Fish sampling}

Fish specimens were collected in November 2010, during the dry period. The dry period is ideal to test spatial variation in biological attributes, since it maximizes differences among streams, and it is when local factors show the strongest association with aquatic fauna (Thomaz et al. 2007; Benone et al. 2018). A 50-meter reach was defined at each stream site, and fish sampling was conducted using hand nets with 2-mm mesh during a six-hour period, by three or four collectors. Fishes were killed with lethal doses of clove oil (Civil House, Federal Law no 11.794 of October 8, 2008), fixed in 10\% formalin, and then conserved in $70 \%$ alcohol. Voucher specimens of $C$. arnoldi were deposited in the ichthyological collection of the Museu Paraense Emílio Goeldi, voucher number MPEG23411.

\section{Data analysis}

Stomach contents of 10 individuals of $C$. arnoldi per stream were analyzed under a stereoscopic microscope. Empty stomachs were not considered for further analyses. Food items were identified and quantified by frequency of occurrence (FO\%) and a semi-quantitative assessment of the dominance of the item (D\%) based on the feeding preference degree (FPD; Braga 1999). FPD may be used to quantitatively describe stomach contents when items are too small or fragmented to allow volumetric or gravimetric measurements. FPD scores items in each stomach content from 1 (low dominance) to 4 (total dominance, i.e. only this item was consumed). Then, $\mathrm{D} \%$ was calculated as the ratio of the sum of the scores of each item to the total assigned scores. The relative importance of the food items for the species and for each stream was calculated by the alimentary Index (IAi; Kawakami and Vazzoler 1980): $\mathrm{IAi}=\mathrm{FOi} \% * \mathrm{Di} \% /\left(\sum \mathrm{FOi} \% * \mathrm{Di}\right) * 100$, where $\mathrm{i}=1,2, \ldots n$ food items; FOi $=$ frequency of occurrence of item $i$; and Di $=$ dominance of the item $i$. As $\mathrm{D} \%$ evaluates the proportion of the food items in each stomach content, it can be used in the alimentary index equation.

The feeding strategy was analyzed by the graphical method of Amundsen et al. (1996), based on the frequency of occurrence and prey-specific abundances (using D\%) of food items. Food items are plotted in Amundsen's diagram and their position in the bivariate space indicate feeding strategy, importance of each food item for the population, and importance of the individuals niche breadth and niche overlap to the population's niche breadth. The higher the value in the horizontal axis, the higher the number of individuals in the population that consumed the food item, reaching 1 when all individuals consumed the given item. The higher the value in the vertical axis, the higher the specialization in the food item. The niche breadth of the population is determined by the diet breadth and overlap of the individuals. A generalist population with high niche breadth, for example, may be composed by generalist individuals with high niche overlap (high within-phenotype component and high values in the horizontal axis) or by specialist individuals with low niche overlap (high between-phenotype component and high values in the vertical axis and low values in the horizontal axis).

We estimated the niche breadth by Levins' index: $\mathrm{BA}=$ $1 / \sum \mathrm{Pi}^{2}$, where $\mathrm{BA}=$ Levins' index, $\mathrm{Pi}$ is the proportion of the diet consisting of the item $i$. BA ranges from 1 (specialist) to $n$ (generalist), where $n$ is the total number of food items. All indices were calculated in the R environment (see supporting information below).

We used a redundancy analysis (RDA) to evaluate how spatial differences in environmental factors (stream width, stream depth, canopy cover and flow as independent factors) explained the variation in the diet composition of the species (dependent factor). We used the Hellinger transformation on the chi-squared proportional dominance of prey items consumed by each specimen and environmental data were standardized before analysis. A multiple regression was used to test how environmental factors explained variation in the niche breadth. Analyses were performed in the vegan package in the $\mathrm{R}$ environment.

We provide supporting information, $\mathrm{R}$ scripts and datasets (dietary information of each individual, as well as alimentary indices and measured environmental conditions for each stream) in the Figshare digital repository: 10.6084/ m9.figshare. 8866055 .

\section{RESULTS}

We analyzed 200 individuals with standard length ranging from $18.8 \mathrm{~mm}$ to $39.9 \mathrm{~mm}$ (mean $\pm \mathrm{SD}: 27.5 \pm 4.2$ ). Thirty-nine individuals had empty stomachs (19.5\%). Copella arnoldi consumed 15 food items in the streams of the National Forest of Caxiuanã and exhibited an omnivorous diet predominantly composed by detritus (Table 1 ). Besides sediment/detritus (IA\% $=66.1 \%$ ), stomach contents of $C$. arnoldi were composed mainly by Formicidae (16.4\%) and insect remains (14.6\%), a food item composed by fragmented parts of insects from which taxon and source (allochthonous or autochthonous) could not be identified.

Stream width ranged from 2.5 to $31.3 \mathrm{~m}(9.09 \pm 8.51)$, stream depth ranged from 0.3 to $1.4 \mathrm{~m}(0.9 \pm 0.4)$, canopy opening ranged from 16.6 to $37.4 \%(27.6 \pm 5.3)$ and stream flow ranged from 0 to $0.14 \mathrm{~m} / \mathrm{s}(0.08 \pm 0.04)$. Neither one of these environmental factors affected the diet composition of $C$. arnoldi 
Table 1. Frequency of occurrence (FO\%), dominance (D\%) and alimentary index (IA\%) calculated for food items consumed by Copella arnoldi in 20 streams of the National Forest of Caxiuanã, Pará, Brazil.

\begin{tabular}{|c|c|c|c|}
\hline Items & $\mathrm{FO} \%$ & $\mathrm{D} \%$ & $\mid A \%$ \\
\hline \multicolumn{4}{|c|}{ Allochthonous arthropods } \\
\hline Aranae & 4.3 & 1.9 & 0.2 \\
\hline Blattodea & 1.2 & 0.8 & 0.0 \\
\hline Coleoptera & 3.1 & 1.5 & 0.1 \\
\hline Diptera & 6.2 & 0.0 & 0.0 \\
\hline Formicidae & 36.0 & 21.6 & 16.4 \\
\hline Isoptera & 6.2 & 2.7 & 0.4 \\
\hline Hemiptera & 6.2 & 0.3 & 0.0 \\
\hline Other insects & 6.2 & 2.9 & 0.4 \\
\hline \multicolumn{4}{|c|}{ Autochthonous arthropods } \\
\hline Crustacea & 0.6 & 0.2 & 0.0 \\
\hline Diptera larvae & 4.3 & 0.6 & 0.1 \\
\hline Hydracarina & 1.2 & 0.0 & 0.0 \\
\hline \multicolumn{4}{|c|}{ Insect remains } \\
\hline Insect remains & 42.2 & 16.4 & 14.6 \\
\hline \multicolumn{4}{|c|}{ Vegetal matter } \\
\hline Algae & 13.0 & 5.9 & 1.6 \\
\hline Vegetal remains & 3.7 & 1.6 & 0.1 \\
\hline \multicolumn{4}{|c|}{ Sediment/debris } \\
\hline Sediment/debris & 72.0 & 43.5 & 66.1 \\
\hline
\end{tabular}

$(\mathrm{RDA} ; \mathrm{p}=0.27)$. Variation in diet composition indicated higher within-stream variation than between streams (see supporting information in Material and Methods), but low sample size per stream did not allow us to address this in greater detail.

Niche breadth ranged from 1.02 to 5.26 , and did not exhibit any response to the environmental factors (multiple regression; $\left.\mathrm{R}^{2}=0.2 ; \mathrm{p}>0.7\right)$. Copella arnoldi exhibited a generalist feeding strategy due to the moderate frequency of consumption of sediment/debris, ants and insect remains associated with low to moderate levels of prey-specific abundance for most of the food items (Figure 2). Amundsen's diagram did not show any strong patterns of between-phenotype or within-phenotype importance to the niche breadth. Moderate to highly frequent items with moderate prey-specific abundance values indicated some importance of the within-phenotype component, while moderate values of prey-specific abundances of unfrequently consumed items indicated some importance of the betweenphenotype component.

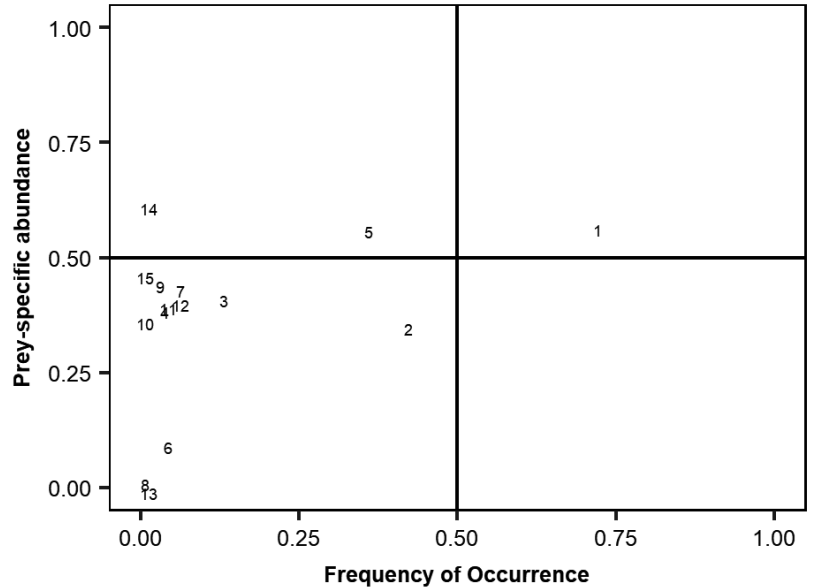

Figure 2. Feeding strategy of Copella arnoldi in 20 streams of the National Forest of Caxiuanã, Pará, Brazil revealed by the Amundsen diagram. Codes: 1 - sediment/ debris; 2 - insect remains; 3 - algae; 4 - plant remains; 5 - Formicidae; 6 - Diptera larvae; 7 - other insects; 8 - Diptera; 9 - Coleoptera; 10 - Crustacea; 11 - Aranae; 12 - Isoptera; 13 - Hydracarina; 14 - Blattodea; 15 - Hemiptera.

\section{DISCUSSION}

Copella arnoldi consumed mainly sediment/debris and allochthonous arthropods, and can be classified as an omnivorous species with a tendency for a detritivorous habit. Despite the environmental variation in the streams of the National Forest of Caxiuaná, $C$. arnoldi exhibited a similar diet composition in all sites, showing no evidence for diet shifts mediated by local-scale changes in the habitat.

Lebiasinids are usually considered as allochthonous insectivores that feed mainly on insects and other arthropods that fall into the water from the riparian vegetation (RománValencia 2004; Kemenes and Forsberg 2014; Silva et al. 2016). This feeding behavior is favoured by occupying the surface of the water column, where the fish picks up food items that fall from surrounding vegetation (Sabino and Zuanon 1998; Brejấo et al. 2013). Nonetheless, Copella arnoldi in our sample fed mainly on detritus/sediment in the streams of the Caxiuaná basin, while Copella nigrofasciata showed moderate detritus consumption in $1^{\text {st }}$ order streams of the Trombetas River basin (Silva et al. 2016).

In addition of surface picking, lebiasinids exhibit grazing as an additional feeding strategy (Sabino and Zuanon 1998). Brejáo et al. (2013), for example, observed numerous lebiasinids browsing periphyton-covered substrate in Amazonian stream impoundments. Waterflow velocity is usually high in headstreams (Vannote et al. 1980), but the low declivity of lowland streams allows debris to accumulate on the bottom of the stream. This is a particularly strong feature in the streams of Caxiuanã, as it is a drowned system with shallow and low flow waters (Benone et al. 2017; Benone et al. 2018). In these environments, debris is a food item that requires low 
energetic investment for search and capture, and it is usually found in the diet of numerous fishes in headwater streams (Kemenes and Forsberg 2014). Given the high abundance of debris in this stream system and the grazing feeding tactics in slow-flow microhabitats, it would be expected for $C$. arnoldi to mainly consume debris/sediment.

Our findings of high detritus/sediment consumption by C. arnoldi contradict previous studies that characterize the diet of lebiasinids as insectivores with a tendency to omnivory. Similarly, Pyrrhulina australis Eigenmann \& Kennedy, 1903 had a different trophic composition in lagoons of the middle Paraná River, based primarily on aquatic larvae of dipterans and cladocerans (Arias and Rossi 2005; Ibarra-Polesel and Poi 2016). Therefore, lebiasinids exhibit a larger variation in their trophic niche than usually assumed, varying from diets composed mainly by allochthonous prey to diets composed mainly by autochthonous prey.

Ants and other allochthonous invertebrates are highly important in the diet of fishes in headstreams (Mendonça et al. 2012; Gonçalves et al. 2013; Silva et al. 2016; Cardoso and Couceiro 2017) mainly due to the low productivity within the streams, which makes these streams highly dependent on the invertebrate input from the riparian vegetation (Vannote $e t$ al. 1980). This input reflects on the predominance of ants in comparison with other allochthonous food items in the diet of $C$. arnoldi and several other Amazonian fishes (Mendonça et al. 2012; Gonçalves et al. 2013; Silva et al. 2016), since ants are highly dominant in the soil macrofauna of Amazonian forests (Fittkau and Klinge 1973). Beyond the high availability, terrestrial arthropods are also high-quality items due to their low C:N ratio (Baxter et al. 2005; Small et al. 2013).

The generalist feeding strategy recorded for Copella arnoldi explains the high variation in niche breadth observed among streams. This feeding strategy is common in tropical lotic systems (Silva et al. 2016) and in other lebiasinids (Arias and Rossi 2005; Silva et al. 2016), and is related to the unstable allochthonous input. This population of $C$. arnoldi is composed of generalist individuals that consume debris/ sediment in high frequency and varies in the consumption of secondary items (numerous items with low frequency of occurrence and low to moderate levels of prey-specific abundances). Therefore, both the within-component and the between-component are important to the high niche breadth of the species.

Despite the great variation in the physical structure of the streams and canopy opening, we found no systematic variation in diet composition and niche breadth between streams. We believe this similarity is not caused by movements of individuals across streams. Distances between streams are large and lebiasinids have reduced swimming ability (Sabino and Zuanon 1998). A previous study in the region (Benone $e t$ al. 2018) suggested that fish can move between streams during the flood period, but the same was not observed during the dry period. Additionally, our data is a snapshot of the species diet, reflecting patterns in a smaller temporal scale than movement across distant streams would take.

Land use has profound impacts on the ichthyofauna of Amazonian streams, both in local, catchment and regional scale (Leitão et al. 2017; Brejão et al. 2018). For example, fragmentation leads to functional homogenization of fish communities (Leitão et al. 2017), and local loss of riparian vegetation reduces trophic guilds based on allochthonous food resources (Bojsen 2005; Borba et al. 2008; Ferreira et al. 2012). The National Forest of Caxiuanã harbors a large and well-preserved forest $(-200,000 \mathrm{ha})$ that allies human use, biodiversity conservation and scientific research. National forests are important pieces in the national planning for nature conservation as they comprise a large amount of the sustainable use areas (Rylands and Brandon 2005). The conservation status of our study sites provides an unfragmented riverscape with a continuous forest. These characteristics appear to minimize the effects of small-scale variations in food resources and on the diet of the splash tetra, Copella arnoldi during the dry season. During the wet season, drowned areas reach more than $100 \mathrm{~m}$ into the forest, which may provide a large amount of resources to aquatic fauna.

\section{CONCLUSIONS}

Lebiasinids are generally pictured as links between the terrestrial and aquatic environment as they feed primarily on allochthonous invertebrates. Nevertheless, C. arnoldi fed primarily on detritus in Caxiuanã streams, probably favored by the high accumulation of debris due to the hydromorphological features of these streams. Therefore, lebiasinids exhibit a broad trophic niche diversity and may have an important role in the autochthonous food chain. This importance may be regulated by environmental factors, but we did not find any evidence that the variation in the diet and niche breadth of $C$. arnoldi were related to canopy opening, stream width and depth, or water flow. Sampled streams are located within a protected area that effectively maintains natural conditions in river catchments and surrounding forest. The given local context may minimize small-scale variations in food resources and in the diet of subpopulations of $C$. arnoldi. Information on the natural history of fish species in the Amazon provides knowledge on the ecological processes of aquatic systems that are important for monitoring and management activities. Observed patterns may change temporally as the streamflow and precipitation change through the year. Therefore, further studies should consider the temporal variation in the diet of C. arnoldi and other small-bodied species to fully understand their role linking the terrestrial and aquatic systems and recycling detritus within the aquatic system. 


\section{ACKNOWLEDGMENTS}

We would like to thank the employees of the Ferreira Penna Scientific Station for their assistance in the fieldwork; Coordenação de Aperfeiçoamento de Pessoal de Nível Superior (CAPES) for the senior internship abroad to LFAM (88881.119097/2016-01); Conselho Nacional de Desenvolvimento Científico e Tecnológico (CNPq) for the productivity grant to LFAM (305017/2016-0); Ministério da Ciência, Tecnologia, Inovaçóes e Comunicaçóes (MCTIC) and CNPq for the research scholarship to NLB (200706/2019-7); Fundação de Amparo à Pesquisa do Estado do Rio de Janeiro (FAPERJ) for the PhD scholarship to BES (E-26/200.758/2019); and the Programa de Pesquisa em Biodiversidade (PPBio) for logistic support.

\section{REFERENCES}

Abelha, M.C.F.; Agostinho, A.A.; Goulart, E. 2001. Plasticidade trófica em peixes de água doce. Acta Scientiarum. Biological Sciences, 23: 425-434.

Allan, J.D; Castillo M.M. 2007. Stream ecology: structure and function of running waters. Springer, Heidelberg, 436p.

Amundsen, P.A.; Gabler, H.M.; Staldvik, F.J. 1996. A new approach to graphical analysis of feeding strategy from stomach contents data-modification of the Costello (1990) method. Journal of Fish Biology, 48: 607-614.

Arias, J.; Rossi, L. 2005. Dieta y estrategia alimentaria de Pyrrhulina australe (Pisces, Lebiasinidae). FABICIB, 9: 197-205.

Barbosa, T.A.P.; Barthem, R.B.; Montag, L.F.A. 2015. Feeding ecology of immature Lithodoras dorsalis (Valenciennes, 1840) (Siluriformes: Doradidae) in a tidal environment, estuary of the rio Amazonas. Neotropical Ichthyology, 13: 341-348.

Baxter, C.V.; Fausch, K.D.; Saunders, W.C. 2005. Tangled webs: reciprocal flows of invertebrate prey link streams and riparian zones. Freshwater Biology, 50: 201-220.

Behling, H.; da Costa, M.L. 2000. Holocene environmental changes from the Rio Curuá record in the Caxiuanã region, eastern Amazon Basin. Quaternary Research, 53: 369-377.

Benone, N.L. 2012. Efeitos do espaço e do ambiente sobre assembleias de peixes de igarapés da Amazônia oriental. Master's dissertation, Universidade Federal do Pará, Brazil. 41p. (http://www. repositorio.ufpa.br/jspui/handle/2011/3474). Accessed on 18 Nov 2019.

Benone, N.L.; Esposito, M.C.; Juen, L.; Pompeu, P.S.; Montag, L.F.A. 2017. Regional controls on physical habitat structure of Amazon streams. River Research and Applications, 33: 766-776.

Benone, N.L.; Ligeiro, R.; Juen, L.; Montaf, L.F.A. 2018. Role of environmental and spatial processes structuring fish assemblages in streams of the eastern Amazon. Marine and Freshwater Research, 69: 243-252.

Bojsen, B.H. 2005. Diet and condition of three fish species (Characidae) of the Andean foothills in relation to deforestation. Environmental Biology of Fishes, 73: 61-73.

Borba, C.S.; Fugi, R.; Agostinho, A.A.; Novakowski, G.C. 2008. Dieta de Astyanax asuncionensis (Characiformes, Characidae), em riachos da bacia do rio Cuiabá, Estado do Mato Grosso. Acta Scientiarum. Biological Sciences, 30: 39-54.

Braga, F.M.S. 1999. O grau de preferência alimentar: um método qualitativo e quantitativo para o estudo do conteúdo estomacal de peixes. Acta Scientiarum. Biological Sciences, 21: 291-95.

Brejão, G.L.; Gerhard, P; Zuanon, J. 2013. Functional trophic composition of the ichthyofauna of forest streams in eastern Brazilian Amazon. Neotropical Ichthyology, 11: 361-373.

Brejão, G.L.; Hoeinghaus, D.J.; Pérez-Mayorga, M.A.; Ferraz, S.F.B.; Casatti, L. 2018. Threshold responses of Amazonian stream fishes to timing and extent of deforestation. Conservation Biology, 32: 860-871.

Cardoso, A.C.; Couceiro, S.R.M. 2017. Insects in the diet of fish from Amazonian streams, in western Pará, Brazil. Marine \& Freshwater Research, 68: 2052-2060.

Ceneviva-Bastos, M.; Casatti, L.; Rossa-Feres, D.C. 2010. Meso and micro-habitat analysis and feeding habits of small nektonic characins (Teleostei: Characiformes) in Neotropical streams. Revista Brasileira de Zoologia, 27: 191-200.

Correa, S.B.; Winemiller, K.O. 2014. Niche partitioning among frugivorous fishes in response to fluctuating resources in the Amazonian floodplain forest. Ecology, 95: 210-224.

Ferreira, A.; Paula, F.R.; Ferraz, S.F.B.; Gerhard, P.; Kashiwaqui, E.A.; Cyrino, J.E.; Martinelli, L.A. 2012. Riparian coverage affects diets of characids in neotropical streams. Ecology of Freshwater Fish, 21: 12-22.

Fittkau, E.J.; Klinge, H. 1973. On biomass and trophic structure of the central Amazonian rain forest ecosystem. Biotropica, 5: 2-14.

Freitas, T.M.S.; Prudente, B.S.; Freitas, D.T.H.; Benone, N.L.; Leão H.: Dutra, G.M.; Montag, L.F.A. 2018. Fishes of Caxiuanã National Forest: 20 years (1993 to 2012) of sampling in a protected area in the Eastern Amazon. Boletim do Museu Paraense Emílio Goeldi. Ciências Naturais, 13: 185-204.

Gonçalves, A.F.G.. Prudente, B.S.; Carvalho-Filho, F.S.; Montag, L.F.A. 2013. Feeding ecology of dash-dot tetra Hemigrammus bellottii (Steindachner 1882) in the streams of the Urucu River Basin, Central Amazonia, Brazil. Biota Neotropica, 13: 141-147.

Ibarra-Polesel, M.G.; Poi, A.S.G. 2016. Alimentación de Characidium rachovii (Characiformes: Crenuchidae) y Pyrrhulina australis (Characiformes: Lebiasinidae) em lagunas someras de la província de Corrientes, Argentina. Revista de Biología Tropical, 64: 603-615.

Irion, G.; Müller, J.; Morais, J.O.; Keim, G.; Mello, J.N.; Junk, W.J. 2009. The impact of Quaternary sea level changes on the evolution of the Amazonian lowland. Hydrological Processes, 23: 3168-3172.

Kawakami, E.; Vazzoler, G. 1980. Método gráfico e estimativa de índice alimentar aplicado no estudo de alimentação de peixes. Boletim do Instituto Oceanográfico, 29: 205-207.

Kemenes, A.; Forsberg, B.R. 2014. Factors influencing the structure and spatial distribution of fishes in the headwater streams of the Jaú River in the Brazilian Amazon. Brazilian Journal of Biology, 74: S023-S032.

Leitão, R.P.; Zuanon, J.; Mouillot, D.; Leal, C.G.; Hughes, R.M.; Kaufmann, P.R.; et al. 2017. Disentangling the pathways of land 
use impacts on the functional structure of fish assemblages in Amazon streams. Ecography, 41: 219-232.

Lisboa, P.L.B. 2002. Caxiuanã: populaçōes tradicionais, meio físico e diversidade biológica. Museu Paraense Emílio Goeldi, Belém, $734 \mathrm{p}$.

Mendonça, M.B.; Montag, L.F.A.; Oliveira-Raiol, R.D.; Wosiacki, W.B. 2012. Feeding ecology of two sympatric species of the genus Jupiaba (Characiformes: Characidae) in streams in the Urucu River Basin, AM, Brazil. Uakari, 8: 59-67.

Montag, L.F.A.; Freitas, T.M.S.; Wosiacki, W.B.; Barthem, R.B. 2008. Os peixes da Floresta Nacional de Caxiuanã. Boletim do Museu Paraense Emílio Goeldi. Ciências Naturais, 3: 11-34.

Montag, L.F.A.; Wosiacki, W.B.; Barthem, R.B. 2009. A ecologia da pesca na Floresta Nacional de Caxiuanã. In: Lisboa P.L.B. (Ed.). Caxiuanã: Desafio para a conservação em uma Floresta Nacional na Amazônia. Museu Paraense Emílio Goeldi, Belém, p.629-47.

Nakano, S.; Miyasaka, H.; Kuhara, N. 1999. Terrestrial-aquatic linkages: riparian arthropod inputs alter trophic cascades in a stream food web. Ecology, 80: 2435-2441.

Netto-Ferreira, A.L.; Albrecht, M.P.; Nessimian, J.L.; Caramaschi, E.P. 2007. Feeding habits of Thoracocharax stellatus (Characiformes: Gasteropelecidae) in the upper rio Tocantins, Brazil. Neotropical Ichthyology, 5: 69-74.

Peterson, C.C.; Keppeler, F.W.; Saenz, D.E.; Bower, L.M.; Winemiller, K.O. 2017. Seasonal variation in fish trophic networks in two clear-water streams in the Central Llanos region, Venezuela. Neotropical Ichthyology, 15: e160125.

Peel, M.C.; Finlayson, B.L.; McMahon, T.A. 2007. Updated world map of the Köppen-Geiger climate classification. Hydrology and Earth System Sciences, 11: 1633-1644.

Pusey, B.J.; Arthington, A.H. 2003. Importance of the riparian zone to the conservation and management of freshwater fish: a review. Marine \& Freshwater Research, 54: 1-16.

Recalde, F.C.; Postali, T.C.; Romero, G.Q. 2016. Unravelling the role of allochthonous aquatic resources to food web structure in a tropical riparian forest. Journal of Animal Ecology, 85: 525-536.
Román-Valencia, C. 2004. Sobre la bioecología de Lebiasina panamensis (Pisces: Lebiasinidae) en la Cuenca del río León, Caribe Colombiano. Dablia, 7: 33-35.

Rylands, A.B.; Brandon, K. 2005. Brazilian protected areas. Conservation Biology, 19: 612-618.

Sabino, J.; Zuanon, J.A.S. 1998. A stream fish assemblage in Central Amazonia: distribution, activity patterns and feeding behavior. Ichthyological Exploration of Freshwaters, 8: 201-210.

Silva, J.C.D.; Gubiani, É.A.; Delariva, R.L. 2014. Use of food resources by small fish species in Neotropical rivers: responses to spatial and temporal variations. Zoologia, 31: 435-44.

Silva, N.C.S.; Costa, A.J.L.D.; Louvise, J.; Soares, B.E.; Albrecht, M.P.; Caramaschi E.P. 2016. Resource partitioning and ecomorphological variation in two syntopic species of Lebiasinidae (Characiformes) in an Amazonian stream. Acta Amazonica, 46: 25-36.

Small, G.E.; Torres, P.J.; Schwizer, L.M.; Duff, J.H.; Pringle, C.M. 2013. Importance of terrestrial arthropods as subsidies in lowland Neotropical rain forest stream ecosystems. Biotropica, 45: 80-87.

Teresa, F.B.; Souza, L.S.D.; Silva, D.M.A.D.; Barbosa, H.D.O.; Lima, J.D.; Nabout, J.C. 2016. Environmental constraints structuring fish assemblages in riffles: evidences from a tropical stream. Neotropical Ichthyology, 14: e150185.

Thomaz, S.M.; Bini, L.M.; Bozelli, R.L. 2007. Floods increase similarity among aquatic habitats in river-floodplain systems. Hydrobiologia, 579: 1-13.

Zeni, J.O.; Casatti, L. 2014. The influence of habitat homogenization on the trophic structure of fish fauna in tropical streams. Hydrobiologia, 726: 259-270.

Vannote, R.L.; Minshall, G.W.; Cummins, K.W.; Sedell, J.R.; Cushing, C.E. 1980. The river continuum concept. Canadian Journal of Fisheries and Aquatic Sciences, 37: 130-137.

RECEIVED: 04/08/2019

Accepted: 17/11/2019

ASSOCIATE EDITOR: Helder M. Espírito Santo 